\title{
Notes on Recent Developments
}

\section{The United Nations Mandate on Human Rights and the Environment}

\author{
John H KNOX \\ Henry C Lauerman Professor of International Law, Wake Forest University, \\ Winston-Salem, NC, USA \\ knoxjh@wfu.edu
}

At its most recent session, in March 2018, the UN Human Rights Council reviewed the final reports of the outgoing Special Rapporteur on the issue of human rights obligations relating to the enjoyment of a safe, clean, healthy and sustainable environment. The Council unanimously decided to renew the mandate for another three years and to request the Special Rapporteur to report to the UN General Assembly as well as to the Council in the future. The strong support by the Council for the mandate is another sign of the increasing international recognition of the interdependent relationship of human rights and the environment.

In this note, the current Special Rapporteur explains the history of the mandate, reviews his most recent reports, including his report on Framework Principles on Human Rights and the Environment, and describes the resolution adopted by the Council.

The UN Human Rights Council is the principal human rights body of the United Nations. Composed of $47 \mathrm{UN}$ member states elected by the UN General

(C) JOHN H KNOX, 2018 | DOI:10.1163/24686042-12340023

This is an open access article distributed under the terms of the prevailing CC-BY-NC license at the time of publication. 
Assembly, the Council meets in three regular sessions each year to consider human rights issues. The Council often appoints experts to fulfil mandates, sometimes called 'special procedures.' The experts are independent: they are not employees of the United Nations, receive no salary and are not subject to the control of the UN Secretariat. The mandates are typically designed to promote greater compliance with a particular right (such as the right of freedom of expression or the right to food), to address particular threats (such as torture, arbitrary disappearance or violence against women) or to focus on the human rights of particularly vulnerable groups (such as minorities, migrants or indigenous peoples). Usually, the mandate-holders are named as special rapporteurs, although sometimes they are appointed as members of five-person working groups.

Occasionally, however, the Council appoints independent experts with mandates that focus more on clarification of the norms in a particular area than on promotion of compliance. For example, in 2008, the Council appointed an independent expert, Catarina DE ALBUQUERQUE, to clarify the content of human rights obligations relating to access to safe drinking water and sanitation. ${ }^{1}$ The rights to water and sanitation were not explicitly included in global human rights treaties, such as the International Covenant on Economic, Social and Cultural Rights, but it had become widely understood that the rights were implicitly included as key elements of existing rights, such as the right to the highest attainable standard of health and the right to an adequate standard of living. ${ }^{2}$ In 2010, the UN General Assembly recognized the right to safe and clean drinking water and sanitation as a human right that is essential for the full enjoyment of life and all human rights. ${ }^{3}$ The next year, the Human Rights Council renewed the mandate of the independent expert, changed her title to special rapporteur and requested her, among other things, to promote the full realization of the human right to safe drinking water and sanitation and to identify challenges and obstacles to its full realization. ${ }^{4}$

The mandate on human rights and the environment followed a similar pattern. The foundational human rights instruments, including the Universal Declaration of Human Rights and the two International Covenants, do not

1 See Human Rights Council res. 7/22 (28 March 2008).

2 See e.g. Report of the United Nations High Commissioner for Human Rights on the scope and content of the relevant human rights obligations related to equitable access to safe drinking water and sanitation under international human rights instruments (16 August 2007) A/Hrc/6/3; Committee on Economic, Social and Cultural Rights, General Comment No. 15: The Right to Water (20 January 2003) E/C.12/2002/11.

3 UN General Assembly res. 64/292 (28 July 2010).

4 Human Rights Council res. 16/2 (24 March 2011). 
explicitly recognize a human right to a healthy environment, undoubtedly because they were negotiated before the rise of modern concerns over environmental harm, which date from the late 196os. However, many regional human rights instruments do include such a right, ${ }^{5}$ as do most national constitutions. ${ }^{6}$ Moreover, over the last twenty years, many UN treaty bodies, regional human rights tribunals and other human rights bodies have explained how environmental harm interferes with the full enjoyment of many other human rights, including the rights to life and health. ${ }^{7}$

In March 2012, the Human Rights Council decided to appoint an independent expert to study and clarify the application of human rights obligations relating to the environment and to identify best practices in their use. ${ }^{8}$ The present author had the honour of being appointed to that position later that year.

In the first years of the mandate, the Independent Expert conducted regional consultations with representatives of governments, international organizations, civil society and academics. He also carried out extensive research, with the assistance of attorneys working on a pro bono basis, on the decisions and statements of international bodies on the application of human rights norms to environmental issues. In 2013-14, he published a series of 14 mapping reports, each of which described the relevant statements on human rights and the environment made by one source or set of sources. ${ }^{9}$ In March 2014, he summarized the conclusions of the mapping project in a report to the Council. The report explained that despite the wide variety of sources, they had agreed that in order to protect against environmental harm that interferes with the

5 Examples include the African Charter on Human and Peoples' Rights (27 June 1981) 1520 UNTS 217, art 24, and the Additional Protocol to the American Convention on Human Rights in the Area of Economic, Social and Cultural Rights (17 November 1988) 28 ILM 156, art 11 (declaring that everyone has 'the right to live in a healthy environment').

6 See David R BOYD, The Environmental Rights Revolution: A Global Study of Constitutions, Human Rights, and the Environment (U BC Press 2011).

7 See e.g. Committee on Economic, Social and Cultural Rights, General Comment No. 14: The Right to the Highest Attainable Standard of Health (11 August 2000) E/C.12/2000/4; African Commission on Human and Peoples' Rights, Social and Economic Rights Action Centre v. Nigeria (2001) Communication No 155/96; European Court of Human Rights, Budayeva and others v Russia (2008) No 15339/o2; Tatarv Romania (2009) No 67021/o1; Inter-American Court of Human Rights, Advisory Opinion requested by the Republic of Colombia (2017) No OC-23/17.

8 See Human Rights Council res. 19/10 (22 March 2012). This and all other resolutions and reports concerning the mandate are available at the website of the Office of the High Commissioner for Human Rights <http://www.ohchr.org/EN/Issues/Environment/SREnvironment/Pages/ SRenvironmentIndex.aspx $>$.

9 The reports are available at <http://www.ohchr.org/EN/Issues/Environment/SREnvironment/ Pages/MappingReport.aspx $>$. 
enjoyment of human rights, States have obligations under human rights law. ${ }^{10}$ Those obligations include procedural obligations (including duties to provide environmental information, facilitate public participation in environmental decision making and provide for access to remedies for environmental harm), substantive obligations to regulate governmental and private actors to protect against such harm and additional obligations to protect those who are most vulnerable.

The following year, in March 2015, the Special Rapporteur presented a report to the Human Rights Council identifying more than 100 good practices in the use of these obligations by governments, international organizations and civil society organizations. ${ }^{11}$ At that session, the Council renewed the mandate for another three years. As it had done with the mandate on the rights to water and sanitation, the Council changed the title of the mandate-holder to Special Rapporteur. It requested that he continue to study the human rights obligations relating to the enjoyment of a safe, clean, healthy and sustainable environment and to identify good practices in their use. It added requests that he promote and report on the realization of the human rights obligations relating to the enjoyment of a safe, clean, healthy and sustainable environment, and to work on identifying challenges and obstacles to their full realization. ${ }^{12}$

In his second term, the Special Rapporteur responded to his amended mandate by proceeding on two tracks. He continued to try to clarify the relationship of human rights and the environment, including by issuing reports on climate change and on biological diversity. ${ }^{13}$ At the same time, he took steps to promote the practical implementation of human rights obligations relating to the environment, including by undertaking country visits, receiving communications, working with UN Environment on a series of regional judicial conferences and working with Universal Rights Group and other partners to develop an online web portal with information for environmental human rights defenders. ${ }^{14}$

UN Doc. A/HRC/25/53 (30 December 2013).

UN Doc. A/HRC/28/61 (3 February 2015).

Human Rights Council res. 28/11 (26 March 2015).

12 Human Rights Council res. 28/11 (26 March 2015). 2017) (biodiversity).

14 See the website of the special procedure at $<\mathrm{http}$ ://www.environment-rights.org/>. 
The Special Rapporteur presented his final reports to the Human Rights Council on 5 March 2018. In addition to two reports describing his visits to Mongolia and Uruguay, the Special Rapporteur presented two thematic reports.

One addresses children's rights and the environment. ${ }^{15}$ Building on the work of many others, ${ }^{16}$ it explains that children are especially vulnerable to environmental threats-indeed, more than 1.5 million children under the age of five die annually because of pollution and other avoidable environmental harm. The report describes how this harm interferes with the ability of children to enjoy their human rights, including their rights to life, health and development, to an adequate standard of living and to play and recreation.

The report also describes the obligations of States to protect against such harm. These obligations include duties to provide for environmental education, to develop and disseminate information about environmental threats to children, to consider the views of children in environmental decision making and to provide for effective remedies for environmental harm to children. The report emphasizes that States' discretion to strike a balance between environmental protection and other societal goals is more limited with respect to environmental harm to children because the consequences of such harm are usually far more severe and because children are typically excluded from environmental decision making, even with respect to decisions that will primarily affect them. States must therefore take additional steps to protect them, including by conducting child-rights assessments of proposed policies and actions. Finally, States must take effective measures to ensure that children most vulnerable to environmental harm are able to exercise their rights on an equal basis and that environmental harm does not affect them disproportionately.

15 UN Doc. A/HRC/37/58 (24 January 2018).

16 See eg Committee on the Rights of the Child on the 2016 Day of General Discussion on children's rights and the environment (23 September 2016) <http://www.ohchr.org/ Documents/HRBodies/CRC/Discussions/2016/DGDoutcomereport-May2017.pdf>; the report of another Special Rapporteur, Baskut TUNCAK, on threats to children posed by chemicals and toxic substances (2 August 2016) A/HRC/33/41; the report of the Office of the High Commissioner for Human Rights on climate change and children (4 May 2017) A/HRC/35/13. Moreover, the World Health Organization and UNICEF, among other international agencies, have described the effects of environmental harm on children in detail. See eg UNICEF, Clear the Air for Children: The Impact of Air Pollution on Children (2016); unicef, Unless We Act Now: The Impact of Climate Change on Children (2015); who, Don't Pollute my Future! The Impact of the Environment on Children's Health (2017); wHO, Inheriting a Sustainable World? Atlas on Children's Health and the Environment (2017). 
The other thematic report has a broader scope. In response to requests that the Special Rapporteur develop guidance that clearly and succinctly describes the human rights norms relating to the environment, this report presents sixteen 'framework principles,' which set out the basic obligations of States under human rights law as they relate to the enjoyment of a safe, clean, healthy and sustainable environment. ${ }^{17}$ Each framework principle has a commentary that elaborates on it and further clarifies its meaning. The framework principles do not create new obligations. Rather, the principles and commentary provide practical guidance on how human rights obligations should be implemented in the environmental context.

The first two Framework Principles express the basic interdependence of human rights and environmental protection. Principle One says that 'States should ensure a safe, clean, healthy and sustainable environment in order to respect, protect and fulfil human rights,' and Principle Two says that 'States should respect, protect and fulfil human rights in order to ensure a safe, clean, healthy and sustainable environment.'

A number of the Framework Principles address procedural obligations. Responding to the increasing threats to environmental defenders around the world, Principle Four makes clear that 'States should provide a safe and enabling environment in which individuals, groups and organs of society that work on human rights or environmental issues can operate free from threats, harassment, intimidation and violence.' Principle Five provides that 'States should respect and protect the rights to freedom of expression, association and peaceful assembly in relation to environmental matters.' Other principles describe States' obligations to provide for education and public awareness on environmental matters; provide public access to environmental information; require the prior assessment of the possible environmental impacts of proposed projects and policies, including their potential effects on the enjoyment of human rights; provide for and facilitate public participation in decision making related to the environment; and provide for access to effective remedies for violations of human rights and domestic laws relating to the environment. ${ }^{18}$

Principle Eleven states that 'States should establish and maintain substantive environmental standards that are non-discriminatory, non-retrogressive and otherwise respect, protect and fulfil human rights.' The accompanying commentary lists factors that human rights bodies have taken into account in this respect, including that:

17 UN Doc. A/HRC/37/59 (24January 2018).

18 Ibid Principles 6-10. 
- the standards should result from a procedure that complies with human rights obligations;

- the standards should take into account and, to the extent possible, be consistent with all relevant international environmental, health and safety standards;

- the standards should take into account the best available science;

- the standards must, of course, comply with all relevant human rights obligations; and

- the standards must not strike an unjustifiable or unreasonable balance between environmental protection and other social goals. ${ }^{19}$

Principle Twelve provides that States should ensure the effective enforcement of the standards against public and private actors.

At the international level, Principle Thirteen states that 'States should cooperate with each other to establish, maintain and enforce effective international legal frameworks in order to prevent, reduce and remedy transboundary and global environmental harm that interferes with the full enjoyment of human rights.'

The Framework Principles also address the situation of those who are most vulnerable to environmental harm. Principle Three provides that 'States should prohibit discrimination and ensure equal and effective protection against discrimination in relation to the enjoyment of a safe, clean, healthy and sustainable environment.' The commentary to the principle explains that this language covers both direct and indirect discrimination and provides examples of both in the environmental context. ${ }^{20}$ Principle Fourteen states that 'States should take additional measures to protect the rights of those who are most vulnerable to, or at particular risk from, environmental harm, taking into account their needs, risks and capacities.' The commentary to the principle provides examples of such measures, including the development of disaggregated data on the specific effects of environmental harm on different segments of the population; careful examination of the impacts on the most vulnerable as part of the environmental assessment of proposed projects; and measures to ensure the equitable and effective participation of all affected segments of the population in relevant decision making. ${ }^{21}$ Principle Fifteen says that States should ensure that they comply with their obligations to indigenous peoples and members of traditional communities, including, among other things, by consulting with them and obtaining their free, prior and informed consent

\footnotetext{
$19 \quad$ Ibid Annex, para 33.

$20 \quad$ Ibid Annex, paras 8, 9.

21 Ibid Annex, paras 43-46.
} 
before relocating them or taking or approving any other measures that may affect their lands, territories or resources.

Finally, Principle Sixteen concludes by stating that 'States should respect, protect and fulfil human rights in the actions they take to address environmental challenges and pursue sustainable development.' This makes clear that the obligations of States under human rights law apply even when States are adopting and implementing measures to address environmental challenges and to pursue sustainable development. ${ }^{22}$

This report also explains that, while explicit recognition of the human right to a healthy environment has not been necessary for the development of human rights norms relating to the environment, it is nevertheless significant that the great majority of the countries in the world have recognized the right at the national or regional level, or both. The report briefly reviews some of the advantages of adopting such a right, based on the experience of these countries, including that it has raised the profile and importance of environmental protection and provided a basis for the enactment of stronger environmental laws. ${ }^{23}$ When applied by the Judiciary, it has helped to provide a safety net to protect against gaps in statutory laws and created opportunities for better access to justice. Courts in many countries are increasingly applying the right, as is illustrated by the interest in the regional judicial workshops held by the United Nations Environment Programme and the Special Rapporteur.

On the basis of this experience, the Special Rapporteur recommended that the Human Rights Council consider supporting the recognition of the human right to a healthy environment in a global instrument. He pointed out that a model could be the 2010 General Assembly resolution recognizing the rights to water and sanitation. The content of those rights had been largely developed before the formal recognition of the right, due to the work of the Committee on Economic, Social and Cultural Rights and the then-Independent Expert on the right to water. Similarly, the Special Rapporteur explained that the human right to a healthy environment 'is not an empty vessel waiting to be filled; on the contrary, its content has already been clarified, through recognition by human rights authorities that a safe, clean, healthy and sustainable environment is necessary for the full enjoyment of the human rights to life, health, food, water, housing and so forth. ${ }^{24}$ In other words, the recognition of the right would serve as a simple, clear statement that would capture the meaning of the existing obligations, as described in the Framework Principles.

\footnotetext{
22 Ibid Annex, para 54.

23 Ibid para 13.

24 Ibid para 15.
} 
The Human Rights Council adopted resolution 37/8 on human rights and the environment in the final week of its latest session, in March 2018. Proposed initially by a group of countries including Costa Rica, Maldives, Morocco, Slovenia and Switzerland, the resolution eventually had over 80 co-sponsors and was adopted by consensus. ${ }^{25}$

The resolution welcomed the work of the Special Rapporteur and took note with appreciation of his reports on children's rights and environmental protection and on the framework principles. The Council 'call[ed] upon States to implement fully their obligations to respect and ensure human rights without distinction of any kind, including in the application of environmental laws and policies. ${ }^{26}$ The Council also welcomed the work of the UN Environment Programme in support of the mandate, in helping to clarify the relationship of human rights and the environment, and contributing to the implementation of human rights obligations relating to the enjoyment of a safe, clean, healthy and sustainable environment. ${ }^{27}$

In its resolution, the Council renewed the mandate of the Special Rapporteur for another three years, and requested the Special Rapporteur in paragraph 7 :

(a) To continue to study the human rights obligations relating to the enjoyment of a safe, clean, healthy and sustainable environment, in consultation with Governments, relevant international organizations and intergovernmental bodies;

(b) To continue to identify, promote and exchange views on good practices relating to human rights obligations and commitments that inform, support and strengthen environmental policymaking, especially in the area of environmental protection;

(c) To promote and report on the realization of human rights obligations relating to the enjoyment of a safe, clean, healthy and sustainable environment;

(d) To work on identifying challenges and obstacles to the full realization of human rights obligations relating to the enjoyment of a safe, clean, healthy and sustainable environment and protection gaps thereto, including in the context of sustainable development;

25 Human Rights Council res. 37/8 (22 March 2018). Co-sponsors included States not members of the Human Rights Council.

26 Ibid paras 1, 2, 3.

27 Ibid para 5 . 
(e) To continue to contribute to and participate in, where appropriate, intergovernmental conferences and meetings relevant to the mandate, including at the UN Environment Assembly;

(f) To develop a dialogue, liaise and collaborate with all relevant stakeholders with a view to enhancing public awareness of the human rights obligations relating to the enjoyment of a safe, clean, healthy and sustainable environment;

(g) To conduct country visits and to respond promptly to invitations from States;

(h) To apply a gender perspective by, inter alia, considering the particular situation of women and girls and identifying gender-specific discrimination and vulnerabilities, and addressing good practices where women and girls act as agents of change in safeguarding and managing sustainably the environment;

(i) To work in close coordination, while avoiding unnecessary duplication, with other special procedures and subsidiary organs of the Human Rights Council, relevant UN bodies, agencies, funds and programmes;

(j) To submit an annual report, including conclusions and recommendations, to the Human Rights Council and to the General Assembly.

The last element, in paragraph $7(\mathrm{j})$, is worth emphasizing because it adds a new opportunity for the Special Rapporteur to raise awareness of the relationship between human rights and the environment to a broader audience. For the first time, the Special Rapporteur will be able to address reports to the General Assembly. This will, among other things, allow the Special Rapporteur to raise the possibility of the global recognition of a human right to a healthy a safe, clean, healthy and sustainable environment directly with the body that would be the most appropriate forum to undertake such a recognition, either through a resolution or through another legal instrument.

The current mandate-holder cannot be reappointed to the position, since he is coming to the end of his second and final term. The Human Rights Council is expected to appoint the new Special Rapporteur at its 38th session, in June 2018. 